\title{
Kadar Merkuri Rambut Anak Sekolah di Sekitar Tambang Emas daerah Sulawesi Tengah
}

\author{
${ }^{1}$ Yoseva Ni Made Stella Sarna \\ ${ }^{2}$ Sarah M. Warouw \\ ${ }^{3}$ Jeanette I. Ch. Manoppo \\ ${ }^{1}$ Kandidat skripsi Program Studi Kedokteran Umum Fakultas Kedokteran Universitas Sam \\ Ratulangi \\ ${ }^{2}$ Bagian Pediatri Fakultas Kedokteran Universitas Sam Ratulangi \\ Email: yosevasmara@yahoo.co.id
}

\begin{abstract}
ABSTRAK
Kesehatan merupakan aspek utama dari kecerdasan anak. Anak yang cerdas dapat memajukan daerah dan berpotensi meningkatkan taraf kehidupannya. Aspek lingkungan misalnya kasus merkuri yang dapat merusak otak anak. Kasus akibat merkuri yang pernah terjadi antara lain kasus toksisitas metil merkuri di penambangan emas kota Palu. Hubungan antara kadar merkuri di rambut dan prestasi belajar di sekolah di kota Palu dianalisis dengan analisis koefisien korelasi Pearson. Hasil analisis ini diperoleh $r=0,216$ dengan $\mathrm{p}=0,016$. Hasil analisis ini menyatakan ada hubungan yang bermakna antara kadar merkuri di rambut dan prestasi belajar siswa di sekolah di kota Palu $(\mathrm{p}=0,016)$.

Kata kunci: prestasi (nilai ujian nasional), merkuri, darah dan rambut.
\end{abstract}

\section{ABSTRACT}

Health is a major aspect of the child's intelligence. Bright child can advance regional and potentially improve their lives. Environmental aspects for instance the case of mercury which can damage a child's brain. Cases have occurred as a result of mercury toxicity include cases of methyl mercury in the gold mining town of Palu.

The relationship between mercury levels in hair and achievement in school in Palu city analyzed using Pearson's correlation coefficient. The results of this analysis obtained $r=$ 0.216 with $p=0.016$. The results of this analysis states there is a significant correlation between mercury levels in hair and student achievement in school in Palu $(p=0.016)$.

Keywords: achievement (national test scores), mercury, blood and hair.

Berdasarkan hasil penelitian sebelumnya di Jepang, ditemukan bahwa penduduk sekitar kawasan minamata mengkonsumsi secara rutin ikan yang berasal dari laut di sekitar Teluk Minamata dan ternyata ikan telah tercemar logam merkuri yang berasal dari limbah. Gejala keanehan mental, dan cacat saraf mulai nampak terutama pada anak-anak. Gejala tersebut baru diketahui 25 tahun kemudian sejak gejala penyakit tersebut ditemukan. ${ }^{1}$

Hal itu terjadi juga di Sulawesi Utara tahun 1996 di Teluk Buyat,
Kecamatan Kotabunan, Kabupaten Bolaang Mongondow. Wilayah tambang adalah Desa Ratatotok, perbatasan antara Kabupaten Minahasa Selatan dan Bolaang Mongondow. Setiap hari, sebanyak 2.000 ton tailing disalurkan ke dasar perairan Teluk Buyat. Dari lokasi tambang tailing dialirkan melalui pipa baja sepanjang 10 $\mathrm{km}$ menuju perairan Teluk Buyat di kedalaman 82 meter. Mulut pipa pembuangan tersebut berjarak 900 meter dari bibir pantai Buyat. ${ }^{2}$ 
Laporan dari Pusat Sarana Pengendalian Dampak Lingkungan, Kementrian Lingkungan Hidup, sungai di Indonesia telah banyak tercemar oleh limbah manusia, terutama sungai Lariang di kota Palu Provinsi Sulawesi Tengah telah tercemar oleh merkuri, sirtu (penambangan pasir dan batu), dan aliran hujan yang membuat kekeruhan di air sungai. $^{3}$

Penyerapan unsur yang melebihi nilai ambang batas oleh tubuh manusia akan mengikat secara kuat sejumlah molekul asam amino, haemoglobin, enzim, RNA, dan DNA. Hal ini akan mengarah kepada kerusakan saluran metabolik, hipertensi darah, hiperaktif, dan kerusakan otak. ${ }^{4}$ Peneliti sendiri merasa tertarik untuk melakukan penelitian ini karena merasa perlu untuk mengetahui dampak limbah tambang terhadap prestasi siswa di sekolah kota Palu, yang berlokasi dekat dengan tempat pembuangan limbah tambang emas di Palu. Peneliti telah melakukan kunjungan pendahuluan pada kesempatan sebelumnya sehingga peneliti tertarik untuk melakukan penelitian tersebut.

\section{BAHAN DAN METODE}

Jenis penelitian adalah penelitian survei. Penelitian ini dilaksanakan dari bulan November-Desember 2013 sesuai dengan izin pihak sekolah. Lokasi penelitian berada di ruang kelas sekolah Palu. Keseluruhan sampel penelitian ini adalah siswa SMP Negeri Palu khususnya yang bertempat tinggal di dekat tambang poboya Palu sebanyak 100 siswa. Analisis data yang digunakan dalam penelitian ini adalah analisis deskriptif, dan analisis regresi dengan korelasi koefisien pearson. Sampel penelitian yaitu umur 14-17 tahun.

\section{HASIL PENELITIAN}

Hubungan antara kadar merkuri di rambut dan prestasi belajar di SMP N Palu dianalisis dengan analisis koefisien korelasi Pearson. Hasil analisis ini diperoleh $r=0,216$ dengan $p=0,016$. Hasil analisis ini menyatakan ada hubungan yang bermakna antara kadar merkuri di rambut dan prestasi belajar siswa di SMP N Palu ( $p=0,016)$. Secara grafik hubungan kedua variabel dapat dilihat pada Gambar 1.

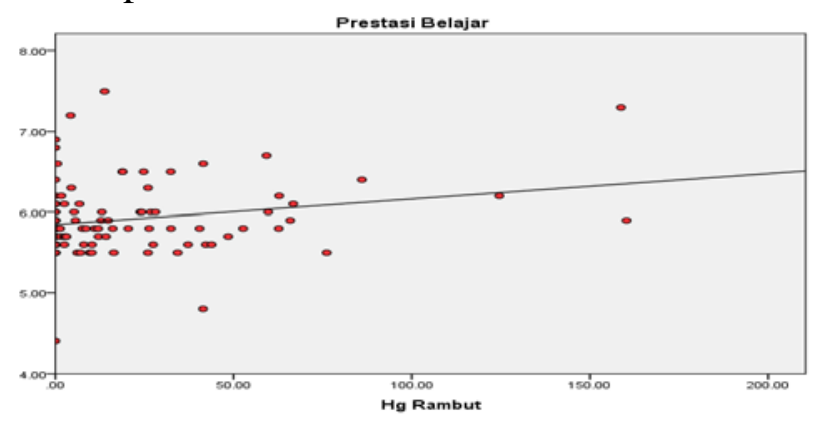

\section{PEMBAHASAN}

Dari hasil penelitian yang telah dilakukan November- Desember 2013 dengan menggunakan metode analisis koefisien korelasi Pearson dan telah memenuhi kriteria sampel untuk diteliti terhadap siswa SMP yang berdekatan bahkan tinggal di lingkungan penambangan poboya dengan total sampel yang berjumlah 100 anak.

Hubungannya dengan darah, metilmerkuri sangat mudah melintas batas sawar darah-otak maupun plasenta. Hal ini lebih disebabkan oleh sifat lifopilisitas yang tinggi dari metilmerkuri. Metilmerkuri sendiri mudah berdifusi melalui membran sel tanpa perlu sistem transport tertentu. Kerena reaktifitasnya yang tinggi terhadap gugus sulfhidril yang terdapat pada berbagai protein, maka jumlah metilmerkuri bebas dalam cairan biologis menjadi sangat kecil. Suatu transpor aktif pada sawar darah otak 
diperkirakan membawa metilmerkuri masuk ke dalam otak. Dalam darah, logam yang sangat neurotoksik ini terikat secara eksklusif pada protein dan sulfhidril berbobot molekul rendah seperti sistein. Kompleks $\mathrm{MeHg}$-sistein yang terbentuk beraksi sebagai analog asam amino, mempunyai struktur mirip metionin, sehingga dapat diangkut oleh pembawa Sistem-L untuk asam amino bebas untuk melintas melalui sawar darah otak.

Hubungannya dengan rambut, asam amino yang penting pada rambut adalah sistein. Metilmerkuri yang bereaksi dan terikat dengan gugus sulfhidril pada sistein kemudian terserap dalam rambut, ketika pembentukan rambut pada folikel. Tetapi, membutuhkan waktu paling tidak sebulan untuk dapat terdeteksi dalam sampel potongan rambut pada pengguntingan mendekati kulit kepala. Tergantung dari panjang rambut pada sampel, konsentrasi merkuri dapat merefleksikan pemaparan merkuri dimasa lalu. Namun, karena waktu paruh merkuri dalam tubuh kira-kira 1,5 - 2 bulan, sampel rambut dekat kulit kepala merefleksikan pemaparan merkuri yang baru terjadi yang juga terkait pada konsentrasi dalam darah pada saat ini. ${ }^{5}$

Di otak merkuri akan terakumulasi di korteks cerebrum dan cerebellum dimana dia berikatan dengan sulfhidril dari protein enzim dan protein seluler sehingga mengganggu fungsi enzim dan transport sel. Merkuri di otak akan menyebabkan sel piknotik yang menunjukkan adanya kerusakan DNA. Gangguan pemaparan ini pada akhirnya akan mengakibatkan nekrosis sel (kematian sel). ${ }^{6}$

\section{SIMPULAN}

Pencemaran merkuri dapat menurunkan prestasi siswa terutama siswa di SMP N Palu.

Ada hubungan antara Hg rambut dengan prestasi.

\section{SARAN}

Sebaiknya anak-anak tidak boleh tinggal di dekat area pertambangan emas. Bagi Dinas Kesehatan agar melakukan penyuluhan tentang dampak limbah merkuri pada masyarakat poboya.

\section{DAFTAR PUSTAKA}

1. Lutfillah K. Kasus newmont pencemaran di teluk buyat. Jurnal Kybernan. 2011 Maret;2(1):18-9.

2. Setiyono A, Djaidah A. Pengaruh konsumsi ikan dann hasil pertanian terhadap kadar hg darah. Kemas. 2012 Januari;7(2):104-10.

3. Pusat Sarana Pengendalian Dampak Lingkungan Kementrian Lingkungan Hidup. Pemantauan kualitas air sungai 33 provinsi dana dekonsentrasi tahun 2011. Banda Aceh. Januari 2012. h.15.

4. Herman DZ. Tinjauan terhadap tailing mengandung unsure pencemar arsen (as), merkuri (hg), timbal (pb), dankadmium (cd) dari sisa pengolahan biji logam. Jurnal Geologi Indonesia. 2006;1:31-6.

5. Yanuar A. Toksisitas merkuri di sekitar kita Departemen Farmasi FMIPA. Universitas Indonesia. h.2-6.

6. Alamudi B, Sianita B, Taufikurohmah T. Pengaruh infiltrasi nanogold terhasap kualitas jaringan dan kuantitas merkuri pada otak mencit (mus musculus) setelah terpapar merkuri. UNESA journal of chemistre. September 2013:2(3):25-31. 